\title{
Isolation, purification and partial physicochemical characterization of a lectin in Andira pisonis Mart seed
}

\author{
Claudia Figueiredo Lossio ${ }^{*}$, Mayara Torquato Lima da Silva, Lia Monteiro Barbosa, Cleane Gomes Moreira, \\ Thaiz Batista Azevedo Rangel Miguel, Antonia Samia Fernandes do Nascimento, Ivanice Bezerra da Silva, \\ Kyria Santiago do Nascimento, Benildo Sousa Cavada
}

From 5th Congress of the Brazilian Biotechnology Society (SBBIOTEC)

Florianópolis, Brazil. 10-14 November 2013

Lectins are ubiquitous proteins in nature, with nonimmune origin, which have at least one non-catalytic domain that binds carbohydrates specifically and reversibly. They can be found in vegetables leaves, stems and seeds. The Dalbergieae tribe has lectins which have specificity for different carbohydrates and also have several biological activities such as induction of rat paw edema, release of chemotactic mediators by macrophages, vasorelaxant effect in rat aortas, among others. This study aimed to isolate, purify and physiochemically characterize a lectin found in seeds of Andira pisonis Mart (Dalbergieae). Andira pisonis Mart seeds were ground into a fine powder and subjected to total protein extraction in $1 \mathrm{M}$ ammonium sulfate. Soluble proteins were subjected to hemagglutination activity quantification by the Bradford method and essays of hemagglutination inibition activity by sugar. The lectin from Andira pisonis Mart (APL) was purified by affinity chromatography on Sepharose- Mannose matrix eluted in $0.1 \mathrm{M}$ glycine buffer $\mathrm{pH} 2.6$ with $0.15 \mathrm{M}$ $\mathrm{NaCl}$. The eluted fraction was dialyzed against distilled water, lyophilized and subjected to ion exchange chromatography on HiTrap SP XL 01. APL was eluted on $20 \mathrm{mM}$ sodium acetate buffer $\mathrm{pH} 4.5$ gradient of $0-1 \mathrm{M} \mathrm{NaCl}$. APL hemagglutinated rabbit erythrocytes (enzymatically treated) and other lectins from the tribe Dalbergieae and showed specificity for mannose $(25 \mathrm{mM})$. SDS-PAGE analysis showed that APL is composed of a major $34 \mathrm{kDa}$ double band and a minor 8 and $9 \mathrm{kDa}$ double band. APL showed thermostability at $60^{\circ} \mathrm{C}$. Further studies are still needed in order to better physicochemically characterize

Universidade Federal do Ceara, Fortaleza, CE, Brazil this protein and study its biotechnological potential on the referred conditions of vasorelaxant effect and chemotatic mediator.

Published: 1 October 2014

doi:10.1186/1753-6561-8-S4-P226

Cite this article as: Lossio et al.: Isolation, purification and partial

physicochemical characterization of a lectin in Andira pisonis Mart seed. BMC Proceedings 2014 8(Suppl 4):P226.

Submit your next manuscript to BioMed Central and take full advantage of:

- Convenient online submission

- Thorough peer review

- No space constraints or color figure charges

- Immediate publication on acceptance

- Inclusion in PubMed, CAS, Scopus and Google Scholar

- Research which is freely available for redistribution

Submit your manuscript at www.biomedcentral.com/submit
() Biomed Central 